\title{
High risk pregnancy in the mare - practical implications for the practitioner
}

\author{
Sara K. Lyle and Dale L. Paccamonti \\ Department of Veterinary Clinical Sciences, School of Veterinary Medicine, Louisiana State University, Baton Rouge, LA (USA)
}

\begin{abstract}
Summary
A variety of problems occur during late gestation that increases the risk of pregnancy loss or poor neonatal survival. Additionally, situations arise where the pregnancy must be terminated in order to save the mare's life. Reproductive conditions that produce a high risk to pregnancy include abnormalities of the umbilical cord, fetal malformations, hydrops allantois, hyrops amnii, placentitis, twin pregnancy, uterine torsion, and prolonged gestation. Non-reproductive conditions that place the pregnancy at risk include ventral ruptures and abdominal wall ruptures, reduced pelvic diameter, gastrointestinal disease, and respiratory disease. These causes can be pre-existing or arise during gestation. Transrectal and transabdominal ultrasonography and endocrine profiling are commonly used to monitor pregnancies determined to be at high risk for fetal loss. Although a specific therapeutic plan will depend on the cause of high risk status, progestins, cyclooxygenase inhibitors, broad spectrum antibiotics, and pentoxifylline are commonly used in many cases of high risk pregnancy. The outcome is highly variable, depending on the cause and how early in the course of disease that an abnormality is identified.
\end{abstract}

Keywords: mare, reproduction, pregnancy, high risk

\section{Risikoträchtigkeit der Stute - praktische Empfehlungen für den Tierarz†}

Während der späten Trächtigkeit treten eine Vielzahl von Problemen auf, die das Risiko einer Fehlgeburt oder der Geburt eines lebensschwachen Fohlens erhöhen. Zusätzlich können Situationen auftreten, in denen die Trächtigkeit abgebrochen werden muss, um das Leben des Muttertieres zu bewahren. Zustände innerhalb der Reproduktionsorgane, die zu einer Risikoträchtigkeit führen, sind: Nabelschnurabnormalitäten, fetale Missbildungen, Hydrops allantois, Hydrops amnii, Plazentitis, Zwillingsträchtigkeit, Torsio uteri und die verlängerte Trächtigkeit. Daneben kann eine Risikoträchtigkeit auch extragenital bedingt sein: Rupturen der Bauchwand, zu schmales Becken, gastrointestinale und respiratorische Erkrankungen. Die Ursachen können präexistent sein oder sich im Zuge der Trächtigkeit entwickeln. Transrektale oder transabdominale Ultrasonographie sowie endokrinologische Untersuchungen gehören häufig zur Trächtigkeitsüberwachung bei drohender Fehlgeburt. Der spezifische Therapieplan hängt von der Risikoursache ab, jedoch gehört die Applikation von Progestagenen, Cyclooxygenasehemmern, Breitspektrumantibiotika und Pentoxifyllinen zu den häufig eingesetzten Therapeutika bei Risikoträchtigkeiten. Die Prognose ist sehr variabel und hängt von der Ursache und dem Zeitpunkt der Diagnose ab.

Schlüsselwörter: Stute, Reproduktion, Trächtigkeit, Risikoträchtigkeit

\section{Reproductive causes of high risk pregnancy}

Abnormalities of the Umbilical Cord

Umbilical cords from normal foals are usually between 36 and $83 \mathrm{~cm}$ (95\% confidence interval) (Whitwell 1975). In a survey of 1,211 abortions from a population of predominantly light breed mares the average length of the umbilical cord was $52.4+14.5 \mathrm{~cm}$ in term foals with normal placentas, while umbilical cords that were excessively long $(71.97+$ $21.7 \mathrm{~cm}$ ) were associated with an increased incidence of umbilical cord torsion, entrapment around the trunk or extremities of the fetus, and long cord/cervical pole ischemia disorder, all of which cause in utero fetal death (Hong et al. 1993). Some twisting of the umbilical cord is common; torsion of the cord is said to have occurred when there is concurrent dilation, edema, thrombosis and hemorrhage of the vessels, and urachal dilation. The incidence of abortion due to umbilical cord torsion in central Kentucky (USA) was reported to be only 4.5\% (Hong et al. 1993). In the United Kingdom, the incidence of torsion due to long cords (37.5\%) appears to be increasing (Smith et al. 2003); perhaps selec- tion for athletic performance has simultaneously selected for genes controlling cord length in certain populations. Excessively short umbilical cords, although less common, have been associated with premature rupture of the cord during delivery with concomitant fetal asphyxiation (Williams 2009). Urachal occlusion has been observed to cause bladder distension and an enlarged abdomen, leading to dystocia. Urachal compression in utero is also thought to be a risk factor for the development of patent urachus in the neonate (Whitwell 1975).

\section{Fetal Malformations}

The incidence of equine fetal monsters is 3 to $7.6 \%$ of all pregnancies, and 8.5 to $10 \%$ of abortions (Crowe et al. 1985, Giles et al. 1993). Schistosomas reflexus occurs when there is a failure of abdominal wall closure during development. Variable spinal and limb deformities are also present. The cause of this error in development is unknown. Abortion can occur at any time during gestation, or be diagnosed at 
term, usually causing dystocia. Other malformations, such as torticollis of the head and neck, scoliosis, and limb contracture are frequently the cause of dystocia in the mare (Hong et al. 1993). The most plausible theory for these malformations is inadequate uterine space for fetal mobility. Posterior or transverse presentations and twin pregnancy can result in compromised space for fetal movements. If delivered alive, many of these foals will regain flexibility as they grow. These defects are not considered to have a genetic component and prognosis for future reproduction is mainly influenced by the severity and sequelae of a resultant dystocia.

\section{Hydrops Allantois and Hydrops Amnii}

Hydrops allantois (hydrallantois) is the rare abnormal accumulation of allantoic fluid (40 to $220 \mathrm{~L}$ ). These mares have excessive abdominal enlargement of a slow or rapid onset, are reluctant to walk or lie down, have decreased food intake and fecal output, and have variable ventral midline edema. Such edema predisposes to ventral midline rupture. Diagnosis is made by transrectal palpation and ultrasonography. The uterus is large, fluid-filled, and protrudes above the pelvic brim. Usually the fetus is not palpable. If diagnosis is made more than 2 to 4 weeks before the expected due date, then elective termination of pregnancy is often recommended in order to save the mare. If close to term, then partial drainage can be attempted, but neonatal survival is poor. Retained placenta, metritis, laminitis, and delayed involution are common sequelae. Abnormalities of the fetus or placenta have been suggested, but there is no conclusive theory on its etiology. Hydrops amnii (hydramnios) is the excessive accumulation of amniotic fluid. The degree of fluid accumulation is not as great as with hydrallantois. It has been seen with malformed fetuses and with normal appearing fetuses. Because hydramnios is rarer than hydrallantois, less is known about its potential etiology. A recent report described conservative management of a case of hydrops amnii resulting in a small live foal delivered at term and a live mare (Christensen et al. 2006).

\section{Placentitis}

Bacterial or fungal infection of the placenta leads to placentitis. The percentage of abortions, stillbirths, and perinatal losses due to placentitis has been reported to range from 9.5 to $33.5 \%$ (Giles et al. 1993, Hong et al. 1993, Hong et al. 1993, Smith et al. 2003). Most cases result from an ascending infection through the cervix; thus the distribution of the lesions extends from the cervical star (Whitwell 1988). Fiftythree percent of losses were due to bacterial infection, and Streptococcus equi subsp. zooepidemicus was isolated in $28 \%$ of these cases (Giles et al. 1993). In Kentucky a unique type of placentitis is seen ('norcardioform', Crossiella equi), with lesions originating from the ventral aspect of the base of one horn (Donahue et al. 2002). Mares with placentitis are usually identified by premature development of the udder, with or without vaginal discharge. Ultrasonographic assessment of the combined thickness of the uterus and placenta (CTUP) has been described with placentitis (Adams-Brendemuehl et al. 1987, Kelleman 2002). Therapy includes antimicrobial agents, anti-inflammatory agents (flunixin meglumi- ne, pentoxifylline), and progestin supplementation (altrenogest) (Macpherson 2006). In utero stress due to infection appears to accelerate hypothalamic-pituitary-adrenal axis activation (Lyle et al. 2009) and neonatal survival; however, these foals have many obstacles to overcome after birth. Placental insufficiency causing poor postnatal growth rates, incomplete ossification of the cuboidal bones, in utero sepsis leading to hypopyon and pneumonia are common sequelae; nursing care can be expensive, and the foal may end up with a poor prognosis as an athlete.

\section{Twin Pregnancy}

The mare's uterus is, in almost all cases, unable to support the growth and nutritional demands of two fetuses. There simply is inadequate endometrial surface area to allow each fetus to grow to the size of a comparable singleton. Many twin pregnancies are reduced early in gestation without intervention (Ginther 1992); the incidence of twin births is $<4 \%$ despite a multiple ovulation rate of as high as $35 \%$ in some breeds. In mares that carry twins beyond the 1 st trimester, the outcome is grim: $64.5 \%$ abort or deliver two dead foals, $21 \%$ deliver a single live foal, and $14.5 \%$ deliver both twins alive (Jeffcott et al. 1973). However, neonatal survivability beyond two weeks for any twin is extremely low. Mares with twins frequently experience dystocia, retained placenta, and delayed interval to next conception. Given these statistics, it is best to reduce twins early in gestation to avoid these outcomes. Manual crush ( $<16$ days), transvaginal ultrasonographicallyguided allantocentesis (day 40-65), transabdomoinal craniocervical dislocation (day 60-110) and transabdominal ultrasonographically-guided cardiac puncture (day 115-130) are options for twin reduction (Wolfsdorf 2006). When twins are not diagnosed until the last half of gestation, little can be done. Supplementation with altrenogest may help in delaying abortion or delivery, allowing for continued in utero development. Unfortunately milk electrolyte concentrations are not reliable of assessing fetal maturity in cases of placental pathology, which includes mares with twins (Rossdale et al. 1991); therefore, inducing delivery is not recommended. Close monitoring for spontaneous delivery or parturition is warranted so that assistance is available if needed.

\section{Uterine Torsion}

Uterine torsion should always be considered as a cause of colic in a mare during the last trimester of pregnancy. Fifty percent of all torsions are diagnosed at parturition, but are responsible for only 5-10\% of dystocias (Pascoe et al. 1981, Vasey 1993). Torsions range from $180-540^{\circ}$, clockwise or counterclockwise; the greater the torsion, the more severe the pain. Diagnosis is by rectal examination of the broad ligaments, since the majority of uterine torsions are cranial to the cervix. Entrapments of small colon, large colon, or small intestines can occur, which significantly increase the severity of pain. The method used to correct uterine torsion will depend on the stage of gestation when the condition is diagnosed. If at term, manual rotation through the cervix can be attempted if the torsion is $<270^{\circ}$ and the mare is tractable. When the condition is diagnosed during the last trimester, the options for correction are laparotomy (standing flank or ventral mid- 
line) or rolling. If surgery is not an option rolling can be attempted in the anesthetized mare. Prognosis for survival of mares overall is good (84\%) and is improved with an earlier stage of gestation. Ninety-seven percent of mares diagnosed before 320 days gestation survived, compared with $65 \%$ surviving when diagnosed after 320 days. Method of correction (rolling, flank laparotomy, ventral midline laparotomy) was not significantly associated with survival. Overall foal survival was $54 \%$ : foal survival was $72 \%$ when torsion occurred at $<$ 320 days gestation, but was only $32 \%$ when torsion occurred at > 320 days. Standing flank laparotomy with torsions < 320 days had significantly improved foal survival compared with ventral midline laparotomy (Chaney et al. 2007).

\section{Prolonged Gestation}

Prolonged gestation is not an uncommon complaint due to the high variability in normal gestation length in the mare. In the majority of cases of true prolonged gestation, placental insufficiency causes in utero growth retardation leading to a delay in maturation of the fetal hypothalamic-pituitary-adrenal axis (HPAA). Until the fetal HPAA is mature, the endocrinological events leading to parturition are delayed. These foals are small for their gestational age and the chorioallantois is thin due to hypoplasia or aplasia of the microvilli. Milk electrolyte concentrations are currently the best method available to assess fetal maturity. Unless the electrolyte concentrations indicate a mature fetus (calcium $>10 \mathrm{mmol}$ or 400 $\mathrm{ppm}$ ) and $\mathrm{K}+(>35 \mathrm{mmol} / \mathrm{L})$ greater than $\mathrm{Na}+(<30$ $\mathrm{mmol} / \mathrm{L})$ (Ousey et al. 1984), avoid the temptation to induce parturition. Failure to base the decision to induce delivery on milk electrolyte concentration usually results in a dysmature fetus that requires nursing care. An exception to this scenario is endophyte-infected fescue (Neotyphodiun coenophialum) ingestion during gestation. The fetus continues to grow in size but the HPAA fails to mature. Abortion, stillbirth, prolonged gestation, dystocia, thickened placenta, agalactia, increased mare mortality and weak foals result. Remove mares from the fescue pasture at 300 days of gestation or treat affected mares with a dopamine antagonist such as domperidone (Redmond et al. 1994).

\section{Non-Reproductive Causes of High Risk Pregnancy}

Ventral Ruptures and Abdominal Wall Ruptures

A defect in the prepubic tendon or ventral abdominal muscles is a relatively uncommon occurrence in the horse, but has extremely dire consequences. It can be seen in older physically unfit mares with a singleton pregnancy, or in mares with abnormal pregnancies (twins, hydrops). As soon as the diagnosis is made, the owner should decide whether survival of the mare or of the foal is most important. If survival of the mare is the goal, then parturition can be induced and assisted (these mares often have ineffective abdominal contractions). If the foal is the owner's priority and the rupture is not complete, the mare can be managed with stall confinement, abdominal supports, analgesics, anti-inflammatory agents, and a low bulk diet. As soon as milk electrolyte concentrations indicate fetal maturity, parturition can be induced and assisted. A recent historical report comparing interventional management (induction or cesarean section) with conservative management found that foal survival was significantly improved with conservative management, and there was no difference in survival of the mare with type of management (Ross et al. 2008). If it is determined that recovery from the rupture is unlikely, the mare should be euthanized immediately following delivery. Most of these mares will not be able to carry a future pregnancy to term. Surgical repair has been attempted in a few cases of incomplete rupture, and some were able to carry a pregnancy to term, but this is the exception rather than the rule. In breeds that allow embryo transfer or other assisted reproductive technologies, pregnancies can be obtained in the future.

\section{Reduced Pelvic Diameter}

Pelvic fractures that have healed with exuberant callus formation are the most common cause of space-occupying lesions in the pelvic canal. The size of the obstruction will determine whether elective cesarean section will be necessary to obtain a live foal.

\section{Gastrointestinal Disease}

Colic happens fairly commonly in the pregnant mare, and fortunately most respond to medical management. Cases of colic requiring surgical intervention or producing endotoxemia put the pregnancy at risk. Any pregnant mare that does not respond quickly to medical management should be closely monitored and early institution of anti-endotoxin therapy and progestin supplementation may avoid abortion or fetal death. If exploratory laparotomy of a late gestation mare is necessary, then altrenogest and flunixin meglumine should be begun prior to surgery. Post-operatively, the health of the fetoplacental unit should be monitored daily by measuring fetal heart rate and the combined thickness of the uterus and placenta (CTUP). Increased CTUP may indicate progressive placental separation (Reef et al. 1996) and impending delivery (Bucca et al. 2005).

\section{Respiratory Disease}

Mares that have lesions causing upper airway obstruction or chronic obstructive pulmonary disease may have inadequate oxygenation of maternal hemoglobin, which can lead to fetal hypoxia. For obstructive lesions, a permanent tracheostomy is an effective solution; however, assistance will likely be needed at delivery due to an ineffective abdominal press. Treatment for COPD is needed if mares have episodes of distress that are difficult to control; oral clenbuterol is effective in many of these cases. Although it is doubtful the dosage of clenbuterol for COPD would interfere with parturition, it is advised to discontinue treatment when the mare appears close to parturition.

\section{Monitoring of the High Risk Pregnancy}

Transabdominal ultrasonography is extremely useful for assessing fetal heart rate, fetal activity, fetal position, charac- 
ter and depth of fetal fluids, and uteroplacental thickness and integrity. Baseline fetal heart rates in the last weeks of pregnancy are 60-75 bpm, with a range of 40-250 bpm. Sustained low or high FHR are cause for alarm. Transrectal ultrasonography is used to evaluate the uteroplacental unit: measurement is made of the CTUP at the ventral uterine body just cranial to the cervix. Finding a CTUP $>8 \mathrm{~mm}$ during the 9th month, $>10 \mathrm{~mm}$ during the 10th month, and $>12 \mathrm{~mm}$ after day 330 signals that placental failure and abortion may occur (Bucca et al. 2005, Reef et al. 1996, Renaudin et al. 1999).

Several hormones are useful to monitor during high risk pregnancies. Progesterone (total progestins) is commonly measured in pregnant mares, although single samples probably are not as informative as serial samples. Precocious increases in progestagens prior to day 315 may be seen with placentitis. Acute declines in progestagens are associated with fetal demise and impending abortion (Ousey 2006). Estrone sulfate is used to monitor fetal well-being, but it is not sensitive in detecting early stages of placentitis. Relaxin is produced by the placenta, and has been found to be decreased in mares with placentitis or signs of endophyte-infected fescue toxicosis (Ryan et al. 2009). At this time, no commercial assay is available for relaxin.

\section{Therapeutics for the High Risk Pregnancy}

The exact list of therapeutic agents needed for an individual mare will vary depending on the reason for the high risk status. However, a few agents are commonly used in many high risk mares: altrenogest, flunixin meglumine, pentoxifylline, and antibiotics. The progestin 17- -hydroxyprogersterone was found to significantly improve the outcome of women with a history of preterm delivery (Meis et al. 2003); this effect is likely due to the reducing the formation of gap junctions in the myometrium (Garfield et al. 1980, MacKenzie et al. 1985), thereby promoting myometrial quiescence. Altrenogest (44 mg q 24 h) prevented pregnancy loss in 8 of 8 cloptrostenoltreated mares while progesterone (300 mg im) prevented pregnancy loss in 5 of 8 cloprostenol-treated mares during the first trimester of pregnancy. In high risk mares, increasing the dosage of altrenogest to $0.088 \mathrm{mg} / \mathrm{kg} \mathrm{q} 24 \mathrm{~h}$ is thought to provide additional tocolytic activity (decreased uterine contractions). More recently, long-acting preparations of progesterone have been shown to be equally effective as altrenogest in preventing prostaglandin-induced luteolysis and pregnancy loss (Vanderwall et al. 2007). Further studies are needed to assess the efficacy of long-acting progesterone in maintaining myometrial quiescence in mares with placentitis. Tocolytic agents, such as magnesium sulfate, $\beta$-sympathomimetic agents (e.g. terbutaline), calcium channel blockers (e.g. nifedipine), prostaglandin synthase inhibitors (e.g. indomethacin, sulindac, aspirin) and oxytocin antagonists (atosiban) either directly or indirectly prevent uterine contractions. Tocolytic therapy is commonly used in human medicine, but is predominantly administered short term $(<2$ d) during which time corticosteroids are administered to accelerate fetal maturity prior to delivery. Injectable clenbuterol is a potent $\beta$-sympathomimetic agent, but is only available in the U.S in an oral preparation. Intravenous clenbuterol $(300$ g) produced uterine relaxation lasting for $120 \mathrm{~min}$ (Card et al. 1995). Subsequently, administration of intravenous clenbuterol to term mares in doses ranging from 600 to $1500 \mathrm{~g}$ failed to alter the length of gestation and there was no difference in the time from injection to delivery compared to controls (Palmer et al. 2002). Debate exists whether oral clenbuterol $(200 \mu \mathrm{g} / \mathrm{kg})$ produces significant reduction in uterine contractions, but given the failure of intravenous clenbuterol to significantly delay parturition, it is unlikely that oral clenbuterol would have a therapeutic effect in inhibiting uterine contractions. Flunixin meglumine, a cyclooxygenase inhibitor, prevents the production of prostaglandins stimulated by endotoxemia. It must be given very early in endotoxemia to avoid luteolysis, which in early pregnancy would lead to abortion (Daels et al. 1991) and was ineffective as a sole treatment in preventing cloprostenol-induced abortion in early pregnancy (Daels et al. 1995). Later in pregnancy, endotoxemia can directly compromise the fetoplacental unit, resulting in abortion. Pentoxifylline $(8.5 \mathrm{mg} / \mathrm{kg}$ po q $12 \mathrm{~h})$ reduces secretion of tumor necrosis factor by equine macrophages (Milam et al. 1992) and has been shown to cross the chorioallantois (Murchie et al., 2003) and therefore is commonly used for mares with placentitis for this presumed anti-inflammatory effect. Possible beneficial secondary effects of pentoxifylline may be through the inhibition of phospodiesterase, leading to reduced respiratory burst in neutrophils and generation of reactive oxygen species (Chilcoat et al. 2002), and increased CAMP leading to smooth muscle relaxation (Ruddock et al. 2005). Vulvar discharges from mares with suspected placentitis are typically contaminated with commensal microflora making isolation of the causative organism difficult. Commonly used broad-spectrum antibiotics with the ability to cross the equine placenta include potassivim penicillin $\mathrm{G}(22,000 \mathrm{lU} / \mathrm{kg} \mathrm{q} 6 \mathrm{~h})$, gentamicin $(6.6 \mathrm{mg} / \mathrm{kg} \mathrm{q} 24 \mathrm{~h})$, and trimethoprim-sulfamethoxazole (30 $\mathrm{mg} / \mathrm{kg} \mathrm{q} 12 \mathrm{~h}$ ) (Murchie et al. 2003). Pentoxifylline, in combination with other therapeutic agents (antibiotics, progestins, and flunixin meglumine) appears to delay pre-term delivery in cases of placentitis (Macpherson 2006, Ousey 2006).

\section{Conclusions}

Many circumstances can lead to high risk pregnancy in the mare. Prompt identification of the nature of the situation is crucial to instituting the appropriate therapy to avoid loss of fetal or maternal life. Unfortunately in many cases an outcome of live mare and live foal is not possible despite the appropriate diagnosis and treatment. Careful client education and communication is necessary to help guide the owner through the decision making process of treatment options.

\section{References}

Adams-Brendemuehl C. and Pipers F. S. (1987) Antepartum evaluations of the equine fetus. J. Reprod. Fertil. Suppl. 35, 565-573

Bucca S., Fogarty U., Collins A. and Small V. (2005) Assessment of feto-placental well-being in the mare from mid-gestation to term: Transrectal and transabdominal ultrasonographic features. Theriogenology 64, 542-557

Card C. E. and Wood M. R. (1995) Effects of acute administration of clenbuterol on uterine tone and equine and fetal and maternal heart rate. Biol. Reprod. Mono 1, 7-11

Chaney K. P., Holcombe S. J., LeBlanc M. M., Hauptman J. G., Embertson R. M., Mueller P. O. and Beard W. L. (2007) The effect of uterine torsion on mare and foal survival: a retrospective study, 1985-2005. Equine Vet. J. 39, 33-36 
Chilcoat C. D., Rowlingson K. A. and Jones S. L. (2002) The effects of cAMP modulation upon the adhesion and respiratory burst activity of immune complex-stimulated equine neutrophils. Vet. Immunol. Immunopathol. 88, 65-77

Christensen B. W., Troedsson M. H. T., Murchie T. A., Pozor M. A., Macpherson M. L., Estrada A. H., Carrillo N. A., Mackay R. J., Roberts G. D. and Langlois J. 2006 Management of hydrops amnion in a mare resulting in birth of a live foal. J. Am. Vet. Med. Assoc. 228, 1228-1233

Crowe M. W. and Swerczek T. W. (1985) Equine congenital defects. Am. J. Vet. Res. 46, 353-358

Daels P. F., Mohammed H. O., Odensvik K. and Kindahl H. (1995) Effect of flunixin meglumine on endogenous prostaglandin F2 alpha secretion during cloprostenol-induced abortion in mares. Am. J. Vet. Res. 56, 1603-1610

Daels P. F., Stabenfeldt G. H., Hughes J. P., Odensvik K. and Kindahl $H$. (1991) Effects of flunixin meglumine on endotoxin-induced prostaglandin F2 alpha secretion during early pregnancy in mares. Am. J. Vet. Res. 52, 276-281

Donahue J. M., Williams N. M., Sells S. F. and Labeda D. P. (2002) Crossiella equi sp. nov., isolated from equine placentas. Int. J. Syst. Evol. Microbiol. 52, 2169-2173

Garfield R. E., Kannan M. S. and Daniel E. E. (1980) Gap junction formation in myometrium: control by estrogens, progesterone, and prostaglandins. Am. J. Physiol. 238, C81-89

Giles R. C., Donahue J. M., Hong C. B., Tuttle P. A., Petrites-Murphy M. B., Poonacha K. B., Roberts A. W., Tramontin R. R., Smith B. and Swerczek T. W. (1993) Causes of abortion, stillbirth, and perinatal death in horses: 3,527 cases (1986-1991). J. Am. Vet. Med. Assoc. 203, 1170-1175

Ginther O. J. (1992) Reproductive Biology of the Mare. 2nd ed. Equisciences, Cross Plains, WI

Hong C. B., Donahue J. M., Giles R. C. Jr., Petrites-Murphy M. B., Poonacha K. B., Roberts A. W., Smith B. J., Tramontin R. R., Tuttle P. A. and Swerczek T. W. (1993) Equine abortion and stillbirth in central Kentucky during 1988 and 1989 foaling seasons. J. Vet. Diagn. Invest. 5, 560-566

Hong C. B., Donahue J. M., Giles R. C. Jr., Petrites-Murphy M. B., Poonacha K. B., Roberts A. W., Smith B. J., Tramontin R. R., Tuttle P. A. and Swerczek T. W. (1993) Etiology and pathology of equine placentitis. J. Vet. Diagn. Invest. 5, 56-63

Jeffcott L. B. and Whitwell K. E. 1973 Twinning as a cause of foetal and neonatal loss in the thoroughbred mare. J. Comp. Pathol. 83, $91-106$

Kelleman A. A., Luznar S. L., Lester G. D., Paccamonti D. L. and LeBlanc M. M. 2002 Evaluation of transrectal ultrasonography combined thickness of the uterus and placenta (CTUP) in a model of induced ascending placentitis in late gestation in the pony mare. in: M.J. Evans (Ed.) Eight International Symposium on Equine Reproduction, pp. 845-848. Theriogenology, Fort Collins, CO, USA

Lyle S. K., Gentry L. R., Horohov D. W., Johnson J. R., Eilts B. E., Godke R. A. and Paccamonti D. L. (2009) Preliminary evidence of fetal hypothalamic-pituitary-adrenal axis activation in an experimental model of infective preterm delivery in the mare Society for Theriogenology Annual Conference, pp., Albuquerque, New Mexico

MacKenzie L. W. and Garfield R. E. (1985) Hormonal control of gap junctions in the myometrium. Am. J. Physiol. 248, C296-308

Macpherson M. L. (2006) Diagnosis and treatment of equine placentitis. Vet. Clin. North Am. Equine Pract. 22, 763-776

Meis P. J., Klebanoff M., Thom E., Dombrowski M. P., Sibai B., Moawad A. H., Spong C. Y., Hauth J. C., Miodovnik M., Varner M. W., Leveno K. J., Caritis S. N., lams J. D., Wapner R. J., Conway D., O'Sullivan M. J., Carpenter M., Mercer B., Ramin S. M., Thorp J. M., Peaceman A. M. and Gabbe S. (2003) Prevention of recurrent preterm delivery by 17 alpha-hydroxyprogesterone caproate. $\mathrm{N}$. Engl. J. Med. 348, 2379-2385

Milam S. B., Mackay R. J. and Skelley L. A. (1992) Secretion of tumor necrosis factor by endotoxin-treated equine mammary exudate macrophages: effect of dexamethasone and pentoxifylline. Cornell Vet. 82, 435-446
Murchie T. A., Macpherson M. L., LeBlanc M. M., Luznar S. and Vikkroy T. W. (2003) A microdialysis model to detect drugs in the allantoic fluid of pregnant pony mares Proceedings of the 49th Annual Convention of the American Association of Equine Practitioners, pp. 118-121, New Orleans, Lovisiana, USA

Ousey J. C. (2006) Hormone profiles and treatments in the late pregnant mare. Vet. Clin. North Am. Equine Pract. 22, 727-47

Ousey J. C., Dudan F. and Rossdale P. D. 1984 Preliminary studies of mammary secretions in the mare to assess foetal readiness for birth. Equine Vet. J. 16, 259-263

Palmer E., ChavattePalmer P., Duchamp G. and Levy I. (2002) Lack of effect of clenbuterol for delaying parturition in late pregnant mares. Theriogenology 58, 797-799

Pascoe J. R., Meagher D. M. and Wheat J. D. (1981) Surgical management of uterine torsion in the mare: a review of 26 cases. J. Am. Vet. Med. Assoc. 179, 351-354

Redmond L. M., Cross D. L., Strickland J. R. and Kennedy S. W. (1994) Efficacy of domperidone and sulpiride as treatments for fescue toxicosis in horses. Am. J. Vet. Res. 55, 722-729

Reef V. B., Vaala W. E., Worth L. T., Sertich P. L. and Spencer P. A. (1996) Ultrasonographic assessment of fetal well-being during late gestation: Development of an equine biophysical profile. Equine Vet. J. 28, 200-208

Renaudin C. D., Liu I. K. M., Troedsson M. H. T. and Schrenzel M. D. 1999 Transrectal ultrasonographic diagnosis of ascending placentitis in the mare: A report of two cases. Equine Vet. Educ. 11, 69-74

Ross J., Palmer J. E. and Wilkins P. A. (2008) Body wall tears during late pregnancy in mares: 13 cases (1995-2006). J. Am. Vet. Med. Assoc. 232, 257-261

Rossdale P. D., Ousey J. C., Cottrill C. M., Chavatte P., Allen W. R. and McGladdery A. J. (1991) Effects of placental pathology on maternal plasma progestagen and mammary secretion calcium concentrations and on neonatal adrenocortical function in the horse. J. Reprod. Fertil. Suppl. 44, 579-590

Ruddock M. W. and Hirst D. G. (2005) Pentoxifylline inhibits agonistinduced vasoconstriction in vascular smooth muscle and spontaneous peristalsis in isolated ileum. Oncol. Res. 15, 81-86

Ryan P. L., Christiansen D. L., Hopper R. M., Bagnell C. A., Vaala W. E. and Leblanc M. M. (2009) Evaluation of systemic relaxin blood profiles in horses as a means of assessing placental function in high-risk pregnancies and responsiveness to therapeutic strategies. Ann. N. Y. Acad. Sci. 1160, 169-178

Smith K. C., Blunden A. S., Whitwell K. E., Dunn K. A. and Wales A. D. (2003) A survey of equine abortion, stillbirth and neonatal death in the UK from 1988 to 1997. Equine Vet. J. 35, 496-501

Vanderwall D. K., Marquardt J. L. and Woods G. L. (2007) Use of a Compounded Long-Acting Progesterone Formulation for Equine Pregnancy Maintenance. J. Equine Vet. Sci. 27, 62-66

Vasey J. R. (1993) Uterine torsion. In: A.O. McKinnon, J.L. Voss (Eds.), Equine Reproduction. Lea \& Febiger, Philadelphia, pp. 457

Whitwell K. E. (1975) Morphology and pathology of the equine umbilical cord. J. Reprod. Fertil. Suppl. 599-603

Whitwell K. E. (1988) Infective placentitis in the mare. In: D.G. Powell (Ed.) Equine Infectious Dieseases. University Press of Kentucky, Lexington, KY, pp. 172-180

Williams N. M. (2009) Causes of abortion. In: N.E. Robinson, K.A. Sprayberry (Eds.), Current Therapy in Equine Medicine, 6th Ed. Saunders Elsevier, St. Louis, MO, pp. 836-842

Wolfsdorf K. E. (2006). Management of Postfixation Twins in Mares. Vet. Clin. North Am. Equine Prac. 22, 713-725

Sara K. Lyle, DVM, PhD

Department of Veterinary Clinical Sciences

School of Veterinary Medicine

Louisiana State University

Baton Rouge, LA (USA)

slyle@lsu.edu 